\title{
CROATIAN WINE TOURISM FROM THE WINERY PERSPECTIVE: THE CASE OF THE GRAND CRO
}

\author{
Matea Hanžek ${ }^{1}$ \\ Gordi Sušić ${ }^{2}$
}

DOI: https://doi.org/10.31410/tmt.2019.669

\begin{abstract}
The paper focuses on importance on wine tourism and explores how Croatian premium small to medium-size wineries can successfully expand into wine tourism and thus enhance and expand their core business activity. In order to access the required data, survey questionnaire was created, conducted and analysed. The sample consists of eight premium Croatian wine estates that form The Grand Cro and encompass: Baković, Bibich, Boškinac, Duboković, Galić, Meneghetti, Petrač and Saint Hill. The research conducted has proved that vintners have justifiable reason to include transition to wine tourism into their future medium-term development strategy because it might help them to drive bottle sales and increases the number of tourists visiting their wineries. More so, through the development of complementary tourist-oriented services, wineries might enhance their brand loyalty and awareness, creating a positive image of their wine product, and consequently the wine region.
\end{abstract}

Keywords: Wine Tourism, Winery, Croatia, Grand CRO.

\section{INTRODUCTION}

A $\mathrm{s}$ the number of tourists in the global wine tourism significantly increased over the past decades, many wineries have developed and promoted wine tourism, seeking new ways to enhance visitor experiences (McDonnell and Hall, 2008). For some destinations, wine roads and wineries present major tourism attractions (Getz, 2000). Furthermore, wine tourism provides a reasonably low-cost distribution channel for selling wines and products associated with wine directly to tourists (Getz and Brown, 2006). Through the development of complementary tourist-oriented services, wineries build brand loyalty and awareness, creating a positive image of the wine product, and consequently wine region and/or particular wine destination within the region (Asero and Patti, 2001; Byrd et al., 2011). Despite recent interest and growing research output, many issues related to tourist interest in the wine tourism and value of perceived wine tourism benefits beyond the core value product have yet to be revealed (Bruwer and Lesschaeve, 2012). This paper therefore aims to reveal whether, how and to what extent such benefits help to drive both bottle sales at selected wineries, as well as the increase of a number of tourists as a part of the wine tourism offer. Because of the increasing importance of wine tourism for many destinations, and because of the important role that wine tourism has in supporting local economies, this research looks at the perceptions of Croatian wine tourism from the winery perspective.

The paper is divided into five parts. It starts with literature review that helps the reader better understand what is meant by wine tourist, wine tourism and the wine tourism destination. The review section also emphasizes the importance of the holistic approach to wine tourism, Croatia's place in the wine world, and value of its wine regions and wine tourism. Secondly, the paper focuses on research methodology and provides a rationale for survey used on a sample of

\footnotetext{
1 Zagreb School of Economics and Management (ZSEM), Jordanovac 110, Zagreb, Croatia
}

2 Zagreb School of Economics and Management (ZSEM), Jordanovac 110, Zagreb, Croatia 
eight small to medium-size wineries that form a part of The Grand Cro wine association. The research results are outlined in the third part and encompass differences between wineries, wine tourism products and trends, marketing and management of wineries, and vintners ${ }^{3}$ opinions. Conclusion and future potential research directions are two final parts of the paper.

\section{LITERATURE REVIEW}

\subsection{Defining the Wine Tourist}

In order to define wine tourism, it is important to consider who travels to wineries as well as what wine tourists expect in such destinations. Byrd et al. (2016) argue that wine tourists can be day-visitors from closer points of origin, or overnight visitors from the immediate area. They possess different demographic characteristics but are often a combination of domestic and international travellers with high socioeconomic level in terms of education, income, and profession (Byrd et al., 2016). With regards to psychological motivation, wine tourist is "someone who has a desire to experience the geographical space where the wine was produced" (Cohen and BenNun, 2009). Many researchers criticized the idea that wine tourists are focused purely on wine. They argued that together with wine, tourists seek for broader experiences connected to wine (Hall et al., 2000; Dodd, 1995; Byrd et al., 2016).

\subsection{Defining the Wine Tourism and the Wine Tourism Destination}

Tourism destinations have evolved over time from focusing on the core winery facility to thinking more broadly in the context of wineries as tourism products and wine regions as tourism destinations. What initially existed was: (1) the grapes and their needs; (2) the natural environment that meets those needs; and (3) vintners who take care of the vineyards through looking at varieties of grapes, spacing the wines, and trellising system to the final products entering bottles (Peters, 1997). More recently, winescape is described as being composed of a combination of vineyards, winemaking activity; and wine tasting (Telfer, 2000). Hall et al. (2000) argue that wine tourists expect seeing grape growing, wine making, picturesque vineyard landscape, and wine tasting room in the wine cellar as a product as a whole, where experience is enriched with wine tasting. Even further, wine tourists combine these with the culture and heritage of a region, as well as local dining and accommodation offers (Cambourne et al., 2000; Bruwer and Alant, 2009). Wine festivals and wine shows create additional wine tourism values (Getz, 2000).

Despite the fact that there is no unique and globally accepted wine tourism definition, wine tourism is closely connected to tourism experiences and motivations. Hall et al. (2000) define wine tourism as "visitation to vineyards, wineries, wine festivals and wine shows for which grape wine tasting and/or experiencing the attributes of a grape region are the prime motivating factors for visitation." The authors further claimed that there are three different stakeholders involved: wine producers, consumers, and tourism agencies. Others argue that wine tourism is at the same time a form of consumer behaviour, a strategy through which destinations develop and market wine-related attractions and imaginary, as well as the wineries who sell their products to customers (Getz and Brown, 2006). Wine tourism, therefore, doesn't exist in wine tourists solely visiting wineries and vineyards to drink and purchase wine but are rather attracted by the expanded winery experiences (wine, gourmet and accommodation).

$3 \quad$ Vintner is a person whose job is to make wine as well as to buy and sell wine. In this research term vintner is used instead of wine maker because owners of examined wineries are not necessarily wine makers but have a variety of other professional and educational background. 


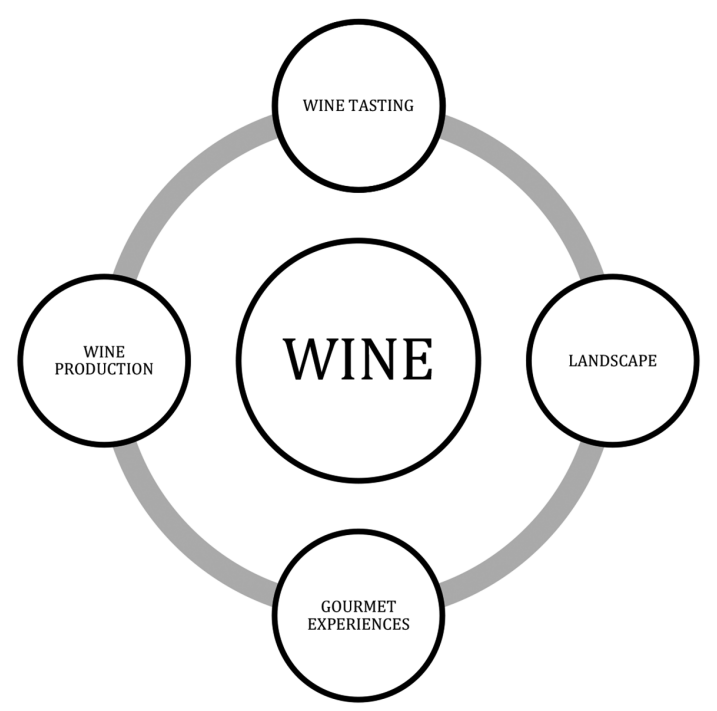

Figure 1. Wine products as a tourist package

Source: Authors

That is why, many wineries today sell their core products (wine) as a package of landscape, wine production, and gastronomic/gourmet experience (Figure 1). Consequently, this paper explores how Croatian premium wineries can successfully expand into the wine tourism through supporting their primary business activity of producing and selling high-quality wine; and, how these core products can successfully be "packed" for the wine tourism.

\subsection{Holistic Approach to Wine Tourism}

The core product in the wine industry as well as in wine tourism is wine (Bruwer and Lesschaeve, 2012). From the perspective of winery, the core production arena in wine tourism would then be grape growing and producing wine. According to a study made by Bruwer (2003), wine tasting and wine purchasing are primary benefits of winery visits. This means that wine tourism benefits should be well connected to the core product. Despite the complexity in understanding the exact relationship between wine production and wine tourism, certain common benefits should be examined. Byrd et al. (2016) proposed model of the core, augmented and ancillary services in the wine region (Figure 2).

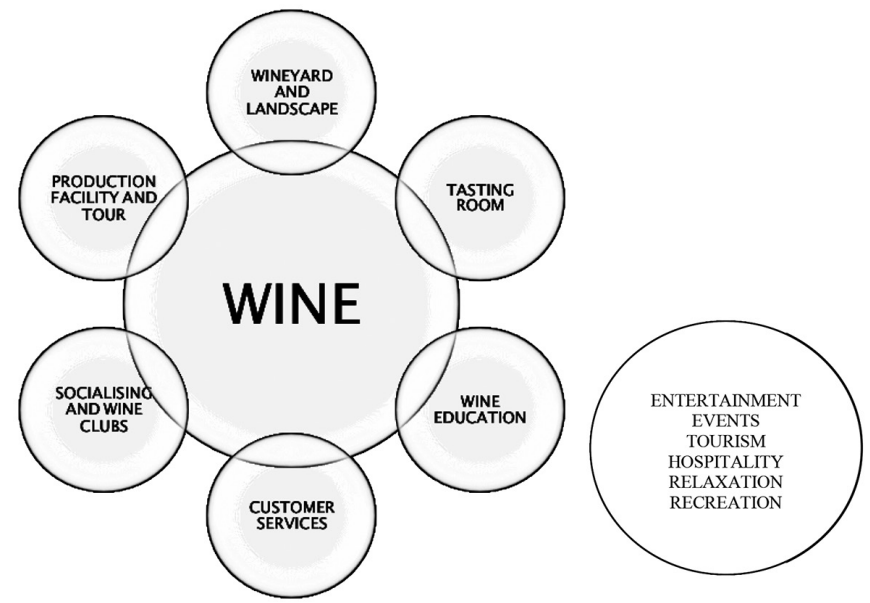

Figure 2. Core, augmented and ancillary services in wine region

Source: Adapted from Byrd et al. (2016:22) 
What this model suggests is that everything starts with a core product. The Core (wine) is represented by the big circle in the Figure 2 above, augmented services on its edge and ancillary services in the separate, outer ring. The core represents (in most cases) the primary reason of a winery visit - the wine itself, its quality and direct consumption (for example, tasting or purchasing the wine). The augmented services pertain to winescape such as vineyard, winemaking activity, wine-tasting facilities, wine education and wine clubs. The third level of services represents relaxation, recreation, events, tourism and hospitality services, accommodation, restaurant, and visitor centres, transportation, all linked, directly or indirectly, to wine.

This research, therefore, explores to what extent examined wineries extended their offer in the context of wine tourism as well as their opinions on the role each of those plays in wine tourism of the small to medium-sized premium Croatian wine estates.

\subsection{The Wine World}

"As anybody who loves wines knows, the regions where the finest wine is made are special places - even magical." (Wine Spectator, 1997)

In general, French wine is often being regarded as one of the premium qualities, with French wine tourism as one of the most cultivated and elevated. The country boasts with rich history and gastronomy and many world-famous wine regions, among them, to name but a few, Alsace, Beaujolais, Bordeaux, Burgundy and Champagne. Some argue that Italy's wine production is bigger that its neighbour's. The country also benefits from beautiful and inspiring countryside, architectural and art achievements and nice climate, key pillars of prosperous (wine) tourism industry. Among its most famous wine regions are Tuscany, Lombardy and Sicily. Spain and Portugal are important wine producers, and regions such as La Rioja, Porto and Alentejo world known for their wine production and scenic beauty. Napa and Sonoma valleys might be considered as the best wine regions in USA, Mendoza in Argentina, Western Cape in South Africa. Each of mentioned wine regions is unique, loved and visited for different reasons, but what is common to all of them is the relatively recent shift from pure emphasis on the wine production to more aesthetic and experiential dimensions (Williams, 2001). The imaginary of wine tourism as a rural paradise presents an important combination of leisure, cuisine, scenery as well as other outdoor activities. The question of how Croatia stands in this respect naturally arises and represents the focal point of this paper.

\subsection{Croatia and The Wine World}

In the case of Croatia, history can be used as an important factor in positioning and placing Croatian wine among the Great wine world maps. The ancient Greeks who colonized the Adriatic region of today's Croatia regularly carried grapevines looking to grow them in the newly occupied colonies (Bakalović, 2018). Romans have developed the viticulture and wine production, while many centuries later, the Austro-Hungarian Empire set the fundaments for more extensive wine production at the same time introducing many previously unknown grape varieties in Croatian wine regions. In Yugoslavia, vintners and entire wine philosophy focused predominantly on the quantity of production, rather than its quality.

Croatia has, since the end of the last century, experienced transition in wine production. From focusing on the yield and quantity, it has shifted to quality. Such change can be seen through 
a continuous increase in the number of wines and quality wines in comparison to table wines and the number of bottled wines in relation to cheaper and bulk wines. The change has started after Croatia gained independence, when some enologists left state-owned wine cooperatives and started their own, initially small wineries. One of the pioneers of this change were Istrian vintners through giving a new treatment to their most popular sort - Malvazia Istarska, implementing new strategies from planting grape to new marketing approaches (Bakalović, 2018). More so, this change positioned Istria as the leading wine destination in Croatia, setting the standards to other Croatian wine regions in developing food and wine tourism.

In general, Croatia can be divided into four basic wine regions covering around 20,000 hectares of vineyards. These are: Istria and Kvarner, Dalmatia, Slavonia and Croatian Danube; and Croatian Uplands (Hrvatsko zagorje). In 2018, their overall wine production was around 750000 hectolitres (Bakalović, 2018). Almost half of the wine production in Croatia is based on the five leading grape varieties: Plavac Mali, Malvazia, Graševina, Merlot and Cabernet Sauvignon.

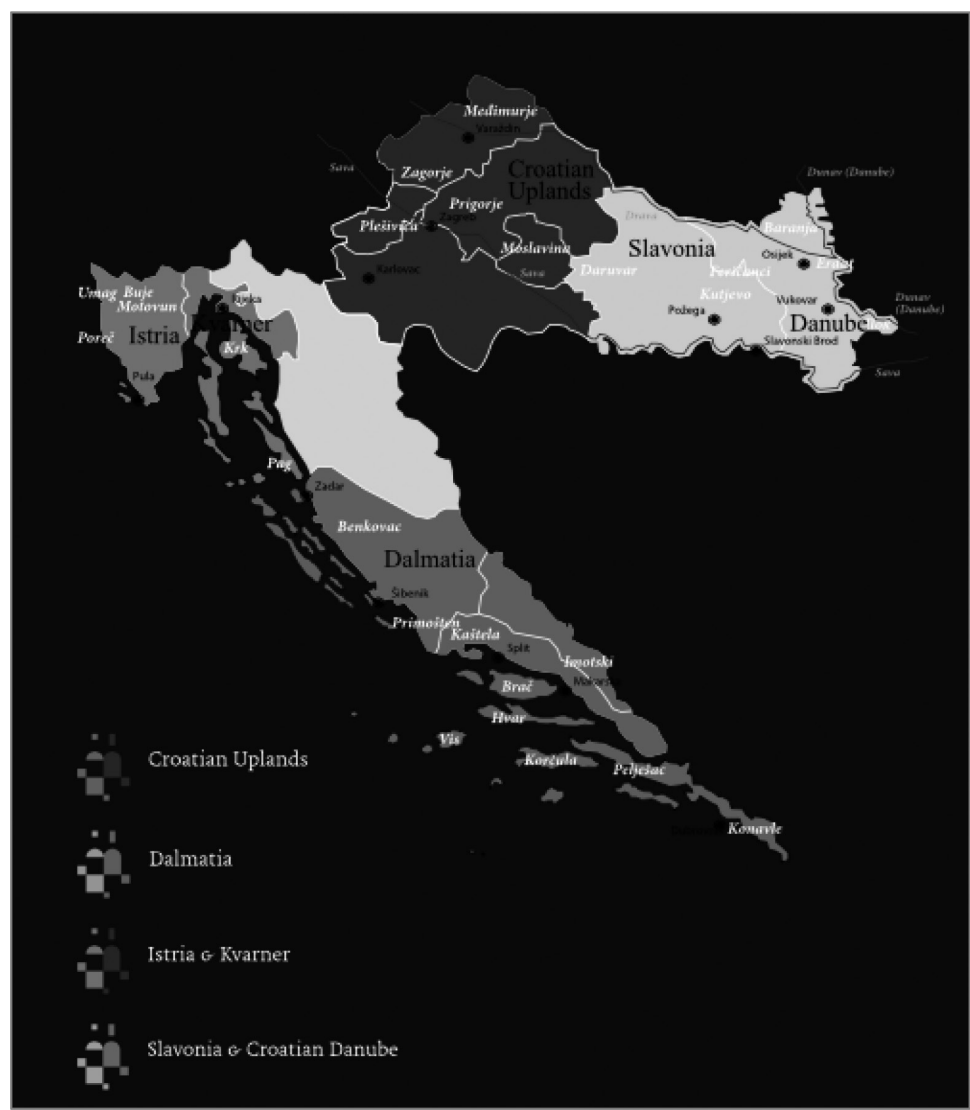

Figure 3. Four basic Croatian wine regions

Source: Adapted from Premium Croatian Wine Estates (2018)

The export of Croatian wines was worth 13 million euros in 2017 (ibid). Traditionally, the largest amount of wines is exported to the neighbouring Bosnia and Herzegovina as well as to Germany (Jakšić et al., 2016). In the context of exports, it is important to mention the so-called "internal export", where a large amount of wine export is consumed by almost twenty million foreign tourists visiting Croatia every year (ibid). There is an increase of the wine tourism segment with the key motivation factor being wine and gastronomy, creating a new opportunity for vintners in expanding their business to the wine tourism segment. Accordingly, this research focuses on how Croatian wineries can strategically approach, enter and prosper from the wine tourism sector. 


\subsection{Croatian Wine Regions and Tourism}

As already mentioned, Croatia can be divided into four basic wine regions. Dalmatia is the origin of the wine civilization of modern Croatia. The first vineyards were planted on islands Vis and Hvar by the Greek colonizers, where Croats settled in the late $7^{\text {th }}$ Century adopting wine tradition they found there (Bakalović, 2018). Protected sorts are Dingač, Postup, Plavac Mali, Babić and Pošip. Dalmatia today stands as one of the most attractive tourism destinations attracting tourists not only by the sun and sea but also searching for other products connected to food and wine. Babić vineyard in Primošten, for example, is a protected UNESCO world heritage site famous for turning the rocky ground into the beautiful vineyards (UNESCO, 2019). Dalmatia is also home to the two out of five Michelin star restaurants in Croatia (Via Michelin, 2019).

As already mentioned, Istria and Kvarner are the most developed wine and wine tourism regions in Croatia. The most popular sorts of wine are Malvazia Istarska, Teran and Žlahtina (Kvarner). Istria was the first region that implemented a strategic way of wine tourism products development; with strong focus on quality, design and combining food with wine offer. This resulted in receiving the first Michelin star restaurant in Croatia. Istria's closeness and good road connections to Venice, Triest, Graz, Vienna, Munich, Ljubljana, and Zagreb, make it a perfect all-year destination.

Slavonia and Croatian Danube are the home of Pannonia, the Central European plain laced with rivers. The turbulent history of this region has left a distinctive mark on the wine culture here. The most important sort of this region is Graševina. Despite being the region mostly developed for the large quantity production of wine, it had only recently started its revitalization towards quality wine production. The best quality Graševina is produced here and is being exported around the world. Concerning tourism, Slavonia started to build a variety of infrastructure to open its vineyards to potential tourists. Many new tasting rooms and hotels have been opened, leading cellars are Ilok and Kutjevo. Wine tourism is seen as a catalyst to revitalize this region after war and devastations of the 1990s.

Croatian Uplands (Zagorje, Prigorje, Plešivica, Moslavina and Međimurje) are close to Zagreb, the Croatian capital, and home of the wine sorts such as Portugizac, Reisling, Sauvignon Blanc, Škrlet and others. In the tourism context, beautiful hills and castles, as well as proximity of Zagreb, attract many tourists to the region.

All mentioned regions started with the revival of their wine production at the end of the $20^{\text {th }}$ Century. There is a huge potential to develop wine tourism and offer tourists many products related to wine and local gastronomy. Many examples show that knowledge and potential exist, however, there is still a long way to go for the region's placement on the EU or global wine tourism map.

\subsection{Premium Croatian Wine Estates: The Case of The Grand Cro}

Within this research, the focus was on the premium Croatian wine estates or, to be more precise, The Grand Cro association. The Grad Cro presents an association gathering the eight Croatian vintners represented by the small premium Croatian wine estates. The member's vineyards, wineries, and wine accommodation are located in different wine regions of Croatia. They share similarities but also specificities in terms on how they approach wine and gastronomy in broader wine tourism perspective. As many tourists choose Croatia for wine and gastronomy, and as 
the list of worldwide restaurants whose wine lists include Croatian wine is growing, The Grand Cro was chosen as a sample for this research. The members of The Grand Cro are: Baković; Bibich; Boškinac; Duboković; Galić; Meneghetti; Petrač; and Saint Hills (Figure 4).

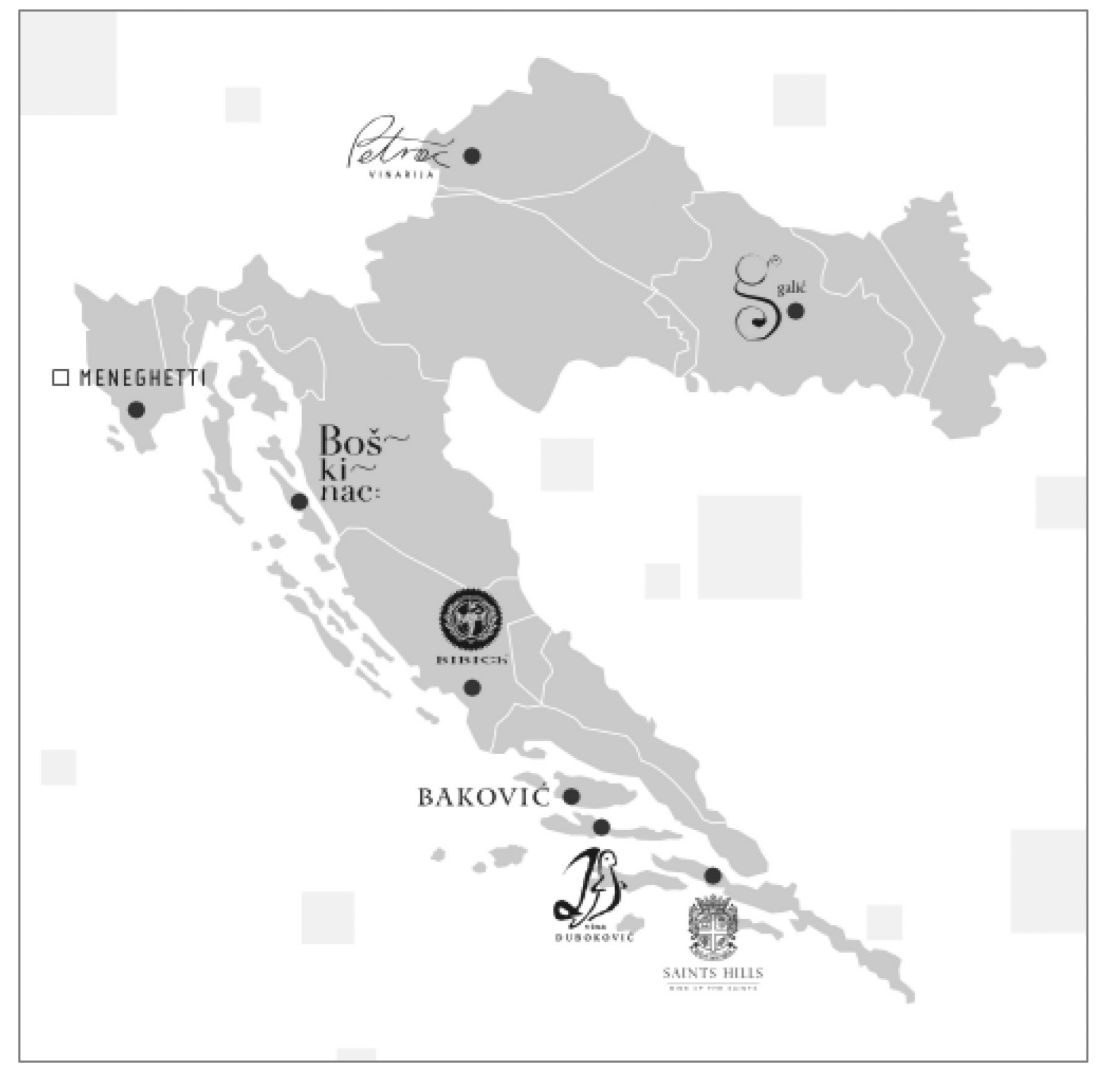

Figure 4. Members of the Grand Cro Association

Source: Adapted from Premium Croatian Wine Estates (2018)

Each of the members took part in this research and findings obtained from survey conducted are presented in the paragraphs that follow.

\section{RESEARCH METHODOLOGY AND METHOD}

The outlined literature review as well as the aims of this research served as the foundation for the survey guideline in this qualitative research. The survey was divided into four sections, each focusing on a certain topic relevant to the research. These topics were: data on wineries, wine tourism products and trends, marketing and management activities, and vintners' opinions. These primary sections were further sub-divided, allowing for the collection of more detailed and categorised data. Each section opened with a more general question and then was followed with a certain number of sub-questions addressing the general one in more detail. Both closed and opened questions were asked with the aim of gathering a qualitative average. The questions, along with the rationale of their inclusion are outlined in Figure 5.

The survey questionnaire was sent out via e-mail to members of The Grand Cro. While analyzing data, each of the eight surveys were looked independently, and then compared and analyzed in order to create meaningful and properly organized data. This data was then used for the purposes of comparing the results of survey taking into account previously made literature review. Finally, comprehensive conclusions were made, presented in research results and discussion that follow. 


\begin{tabular}{ll}
\hline Data on wineries & $\begin{array}{l}\text { This section looks into differences between the wineries, wine } \\
\text { areas, their ownership, etc. }\end{array}$ \\
\hline Wine tourism products and trends & $\begin{array}{l}\text { This section identifies wine tourism products provided by examined } \\
\text { wineries. It also discusses potential future trends in wine tourism } \\
\text { and the way wineries can adapt to them. }\end{array}$ \\
\hline Marketing and management activities & $\begin{array}{l}\text { This section identifies the marketing and management strategies that } \\
\text { are used by wineries and evaluates their successfulness. }\end{array}$ \\
\hline Vintners opinions & $\begin{array}{l}\text { This section focuses on vintners' feelings and opinions concerning } \\
\text { present and future developments in wine tourism, as well as their } \\
\text { co-operation with other tourism stakeholders. }\end{array}$ \\
\hline
\end{tabular}

Figure 5. Questionnaire sections and the rationale of their inclusion in the research

Source: Authors

\section{RESEARCH RESULTS}

Research surveys revealed several common themes that often mirrored the literature review and secondary data collection with regards to the importance of focusing not only on wine as a core product in the process of expanding into the wine tourism market. Research results are discussed are divided into the five main themes: differences between wineries, wine tourism products and trends, marketing and management of the winery, and vintners' opinions, each discussed separately in the text that follows.

\subsection{Differences between wineries}

\section{Ownership model}

As seen in the Figure 6, most of the wineries are established as a limited liability (75\%), while others are registered as family businesses - family farms (25\%).

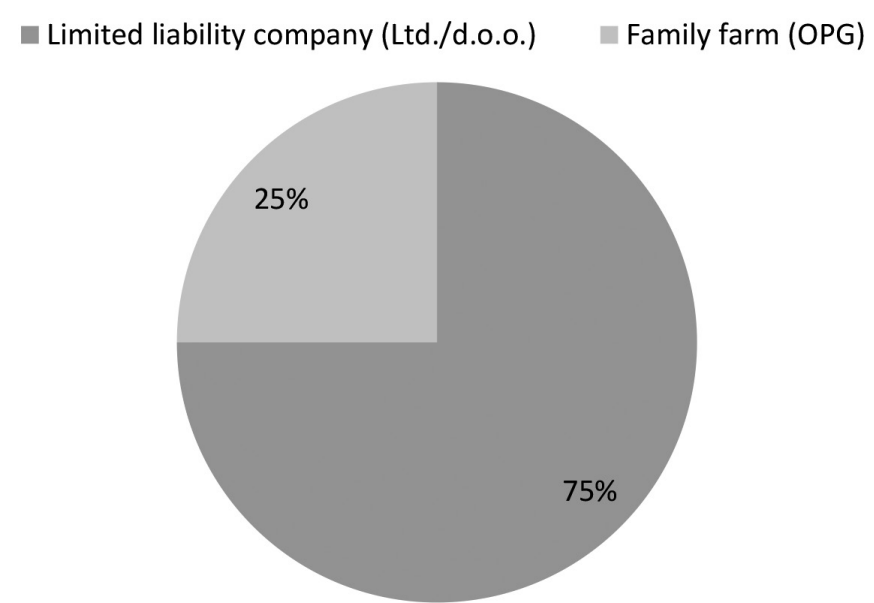

Figure 6. Ownership models of selected Wineries

Source: Authors

Despite most of wineries are small family boutique wineries they still choose limited liability business models (Ltd), which presumably mirrors professional backgrounds of their owners. Only one of The Grand Cro property owners has wine making background. Most of them have a business and entrepreneurship backgrounds, while others have backgrounds in law, sales, engineering and tourism (Figure 7). 


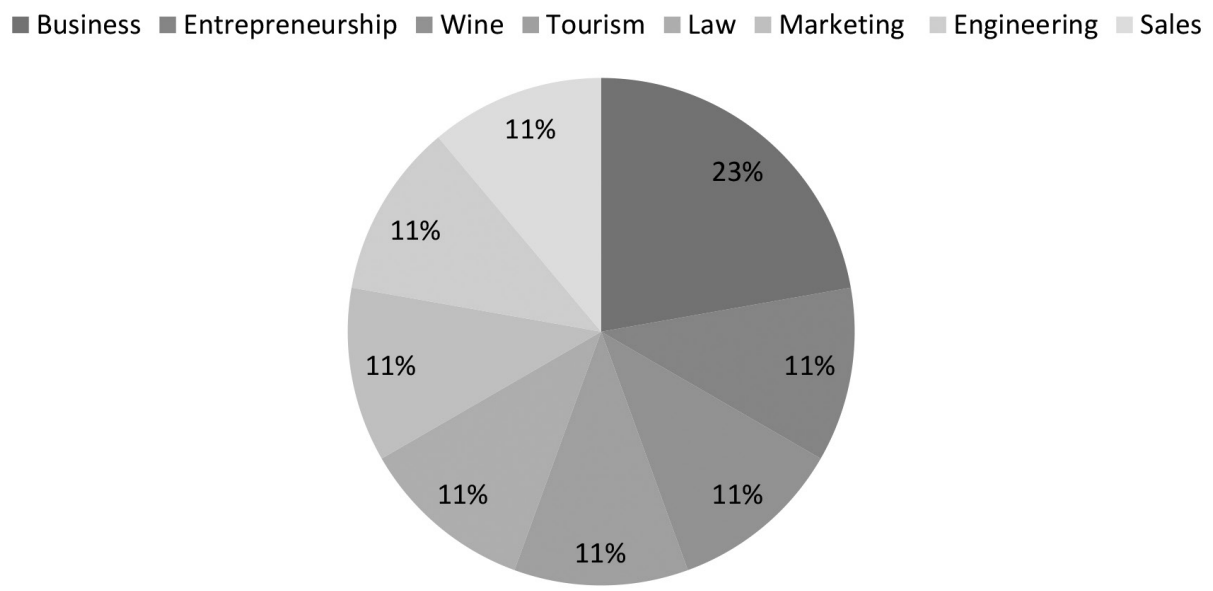

Figure 7. Owners' backgrounds

Source: Authors

\section{Average size of vineyards and Production size}

On average, selected boutique wineries are small to medium sized, and the same can be said about their production. As seen in the Figure 8, most of The Grand Cro vineyards are up to 10 hectares in terms of size (62.5\%), with only one quarter of them exceeding 21 hectares. In terms of wine output, most of selected wineries produce relatively small amounts of wine (less than 50,000 litres), with only a quarter with production surpassing 100,000 litres.

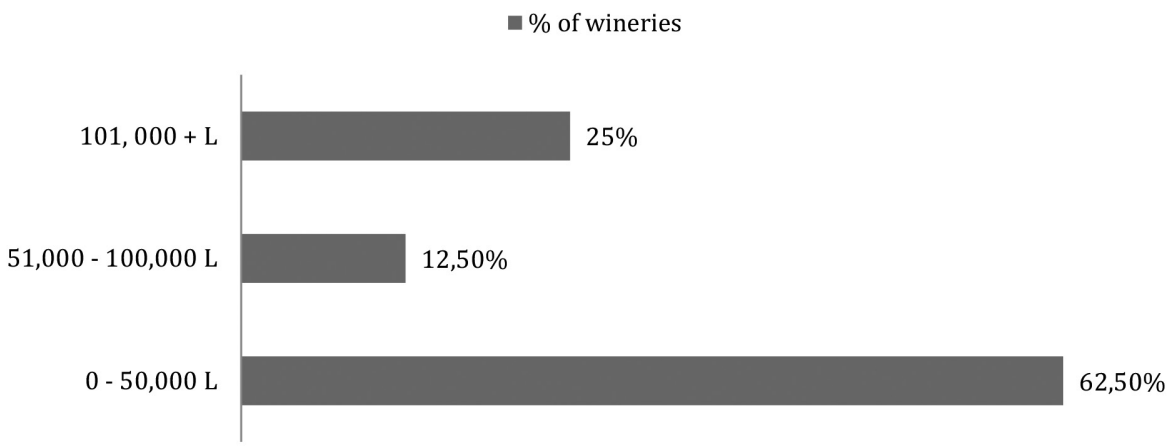

Figure 8. Average vineyard size

Source: Authors

— of wineries

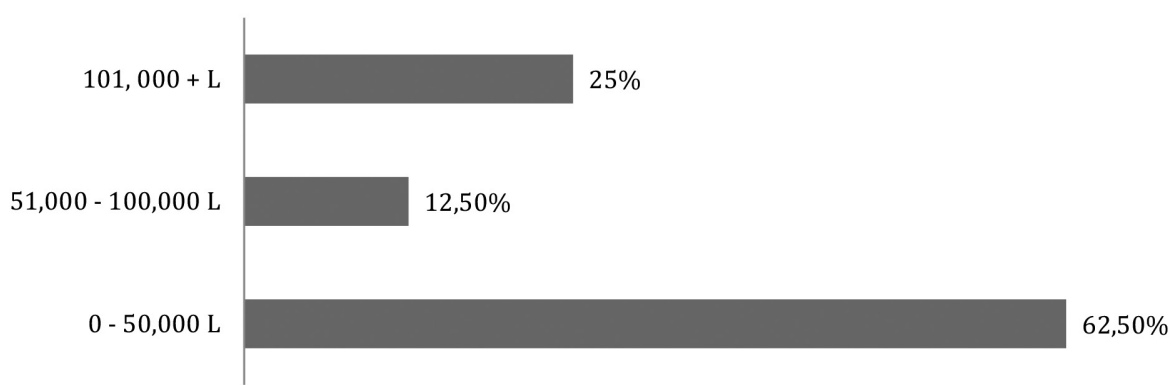

Figure 9. Average production size

Source: Authors 


\section{Entering wine tourism}

The wineries of The Grand Cro have also evolved from focusing on the core winery facility to thinking more broadly in the context of wineries as tourism products (as stipulated, in general, by Byrd et al., 2016). Figure 10 differentiates between wineries that first entered wine production business and only later expanded to wine tourism (75\%) from those that immediately entered both markets $(25 \%)$. Those who immediately entered wine tourism are wineries that recently opened (since 2000) proving that wine tourism is a relatively new phenomenon in Croatia.

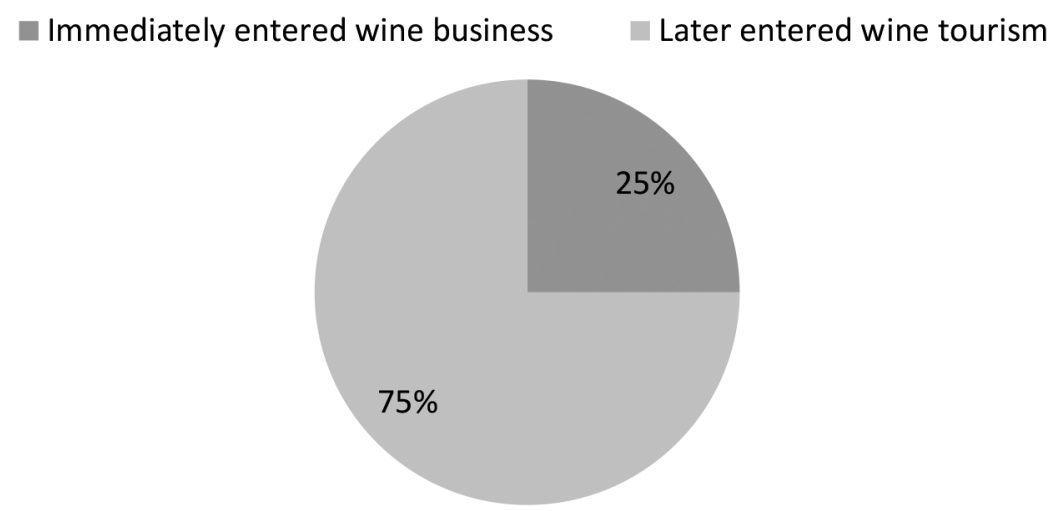

Figure 10. Wineries that expanded to wine business vs. wineries that were immediately in wine tourism

Source: Authors

\section{Employees}

Figure 11 shows percentage of overall employees in surveyed wineries divided into those working in the wine production and those working in the wine tourism related products developed by wineries.

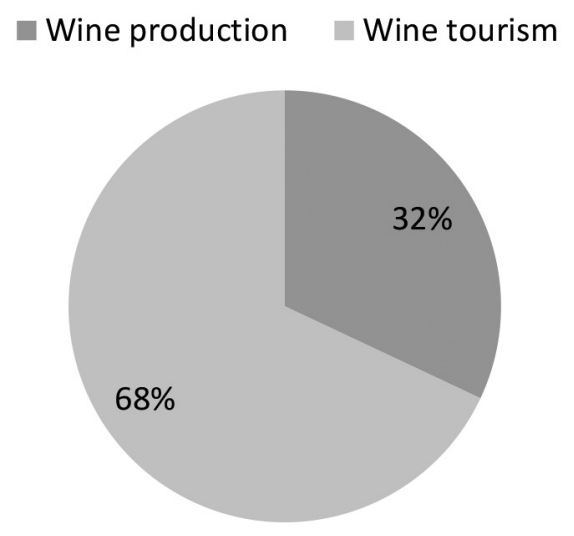

Figure 11. Overall number of employees in winery production vs. number of employees in wine tourism (gastronomy and accommodation of examined wineries)

Source: Authors

The data shows that despite wine production presenting the core product of wineries, once the wineries expand to wine tourism (which is work-intensive sector) they require and employ more hands. 


\subsection{Wine tourism products and trends}

\section{Pull-factor to visit the winery}

As mentioned in the literature review, wine is the core product of winery visit. As seen in the Figure 12, vintners agree wine is the main motive for winery visit.

Wine Wine, gourmet and accommodation

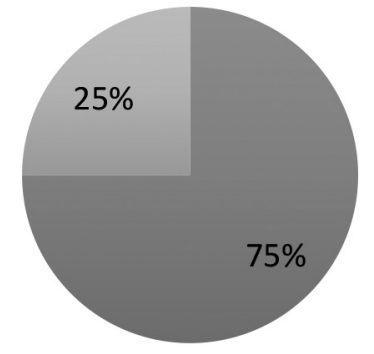

Figure 12. The core motive of the winery visit

Source: Authors

Despite the fact that the core product is wine, theory and global wine industry experience indicate that development of the wine tourism products is crucial for expanding into the wine tourism. To what extent selected Croatian wineries develop their wine tourism related products is the focus of the next paragraph.

\section{Development of wine tourism products}

Most of the wineries recognized benefits of expanding into the wine tourism and have therefore developed variety of the wine tourism products as seen in the Figure 13.

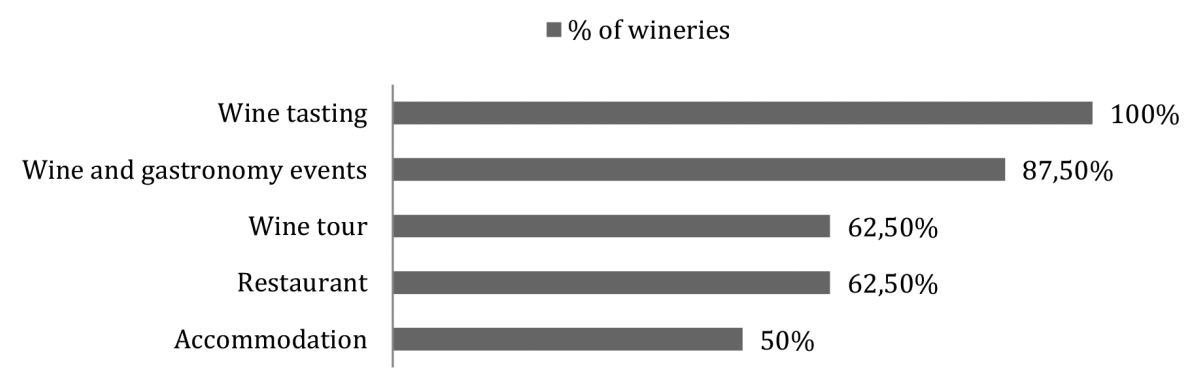

Figure 13. Wine tourism products offered by the selected wineries

Source: Authors

As Telfer (2000) argued the combination of the following elements is needed for proper development of wine tourism products: vineyards, winemaking activity, and wine tasting. More so, Bruwer (2003) argued that wine tasting and wine purchasing are primary benefits of winery visit. As seen in the Figure 12, all wineries have developed wine tasting followed by wine and gastronomy events. Half of them have also developed local dining and accommodation offers, and have by that created the wine products as a tourist package combining wine, gastronomy and accommodation as proposed by Getz and Brown (2006) and through that developed core, augmented as well as ancillary services (Figure 2). 


\section{Relationship between Wine tourism and Wine sales}

In supporting the claim of wine tourism benefiting to increased sales of wine, all vintners have agreed that wine tourism positively impacts wine sales. Figure 14 shows relationship between wineries revenues form wine compared to those from wine tourism.

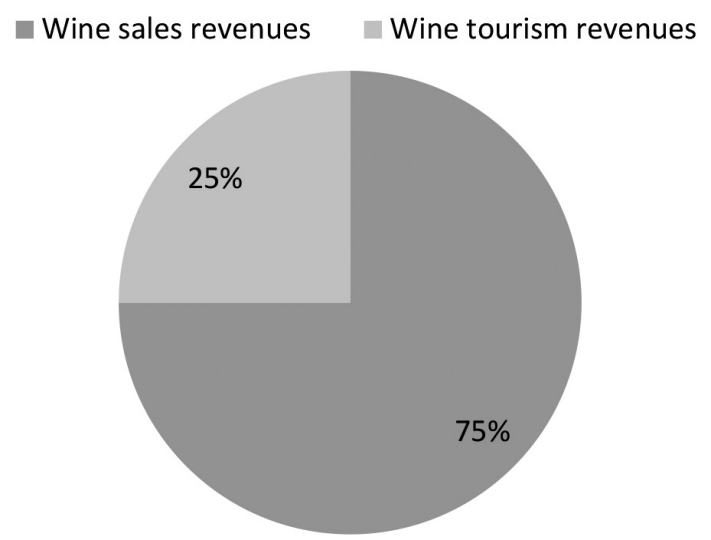

Figure 14. Overall wine revenues vs. wine tourism revenues

Source: Authors

Data shows that most of the wineries still generate more revenues from the wine production business compared to wine tourism. However, if examined closer, those wineries that developed wine tourism consequently have higher overall revenues in wine tourism then in wine production.

\subsection{Current and Future Budget Allocation}

Most of the wineries still allocate more of their budgets into the production of wine $(62.5 \%)$, while somewhat more than $1 / 3$ of their budget is allocated for development of wine tourism. However, by looking at their development plans, as seen in the Figure 15, vintners plan to allocate more in the wine tourism in the future.

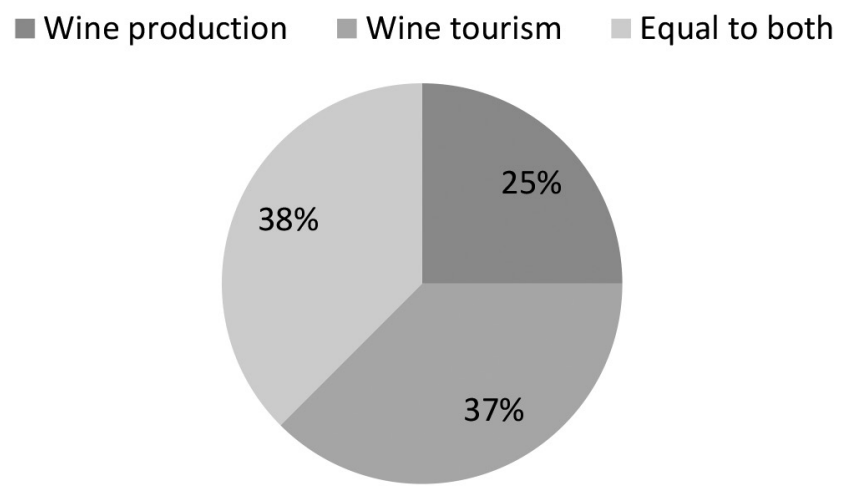

Figure 15. Future budget allocation of selected vineries

Source: Authors

This further confirms that there is an increased recognition of wine tourism segment as a new opportunity that vintners are trying to be a part of. One of the reasons of this shift is response to the change of the trends in wine tourism. As all of the wineries already developed wine production, now they have entered the phase of the wine tourism product development. In order to do 
it successfully, wineries should approach entering wine tourism strategically and marketing oriented. Such approach, foreign experience shows, might be beneficial for the long-term success of these premium Croatian wine estates. Their current approach to marketing and management of winery is discussed below.

\subsection{Marketing and Management of the Winery}

The same person manages winery and wine tourism in $80 \%$ of the examined wineries. Marketing is mostly managed in-house (75\%) and is outsourced only by the minority of wineries $(25 \%)$. The most often used marketing tools are public relations (PR), events and personal sales as seen in the Figure 16.

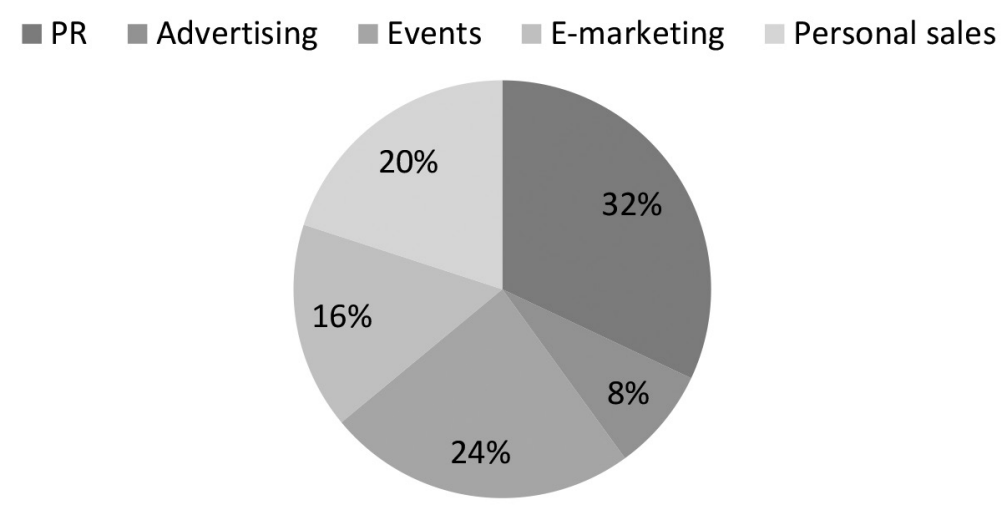

Figure 16. Promotional tools mostly used for marketing of winery and wine tourism

Source: Authors

Examined wineries allocate most of their budget for events (75\%), followed by public relations $(50 \%)$, and then other marketing tools.

\subsection{Vintners Opinions}

\section{Main Challenges}

Despite the confirmation that wine tourism positively impacts their wine sales and brand development, The Grand Cro wineries outlined the main challenges they face in development of wine tourism products (Figure 17).

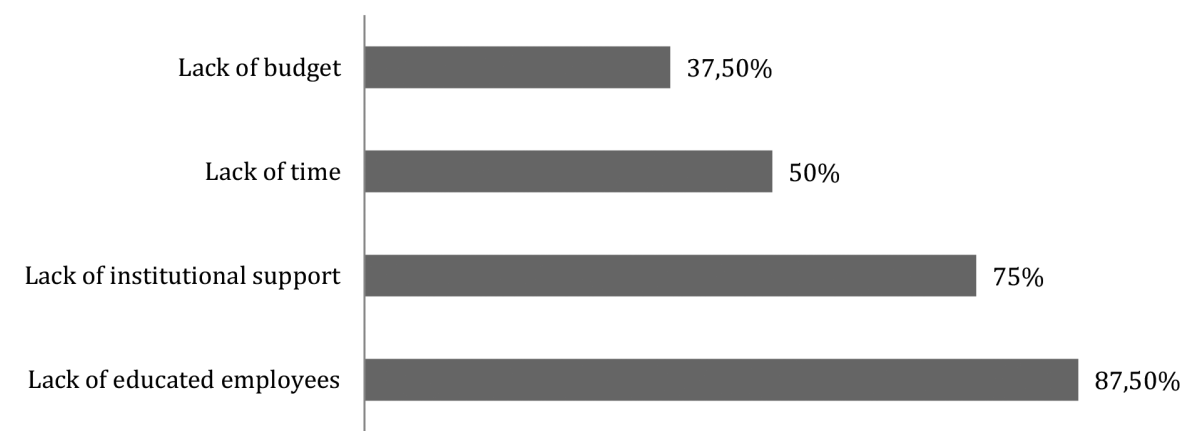

Figure 17. Main challenges vintners face in transition to wine tourism

Source: Authors 
Lack of educated employees is one of the main challenges that vintners face in their transition to wine tourism. More so, they agreed that there is a lack of governmental institutions support in their transitioning to wine tourism as well as time and budget constraints.

\section{Being a part of The Grand Cro}

All members agreed that being the member of Grand Cro association helps them in their core business - wine production as well as in developing wine tourism products. One of the vintners argued:

"It is easier to work on promotion when there is more of us. Through sharing expenses, we can cover more marketing channels and use more tools than we would be able should we do it alone."

Other vintners added:

"It is easier to get governmental funding that is allocated on the yearly basis. The only thing that we lack is long-term planning and vision."

"We're brought together by common interests and aims. We work together and often appear together at fairs. We make different styles of wine, come from different regions of Croatia, and so we don't compete with each other. I believe that through association we can get a lot more done. Now we are in a period when more and more entrepreneurs and winemakers in Croatia understand they have to get together and that synergy will bring a lot more benefits than some imaginary fear of competition".

\section{Support of the Governmental Institutions}

The three main themes were constantly mentioned by vintners with regards to what governmental institutions need to do in order to better support development of wine production and wine tourism. These are: professional help, easier access to funds available for both wine production development as well as wine tourism development, and, finally, reduction of the administrative burden.

\section{Stakeholder Collaboration}

Throughout the research vintners have outlined that better collaboration is needed with other tourism stakeholders, and especially so with Croatian Chamber of Commerce, tourism boards, local communities as well as tourism agencies.

\section{Way Forward}

Way forward for all of the wineries that are part of The Grand Cro, according to their thoughts, is to focus on and to further develop the wine tourism. After developing wine tasting and restaurants, most of the vintners want to invest in small wine hotel developments and different wine tourism products. 


\section{CONCLUSION}

The evidence from this study might be of help and value added for successful transition from wine production to wine tourism of small to medium sized Croatian high-quality wine producers. In Figure 18 a general model for as yet non-existent strategy of other small quality wineries in Croatia is outlined as a possible recommendation to go forward. Recommended path relies on processes suggested by various authors (Byrd et al., 2016; Hall et al., 2000; Bruwer and Lesschaeve, 2012) and consists of four stages. Stage 1 relates to the core business (wine production) and the ongoing process of the brand building and recognition. Ensuing stages are linked to wine tourism. The initial step in this respect (Stage 2) is wine tasting and combination of wine tasting and gastronomic experience. In Stage 3 experience is further expanded by onsite accommodation and finally, in Stage 4, by wine spa, education and clubs.

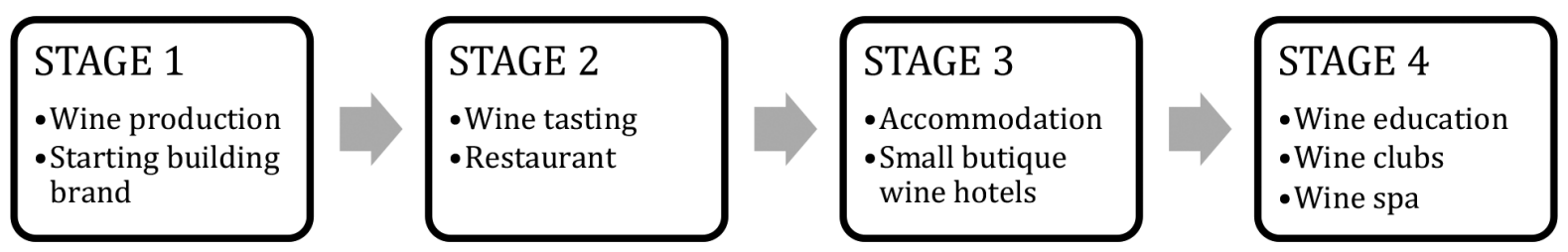

Figure 17. Proposed model for successful transition from wine production to wine tourism for small boutique Croatian wineries

Source: Authors

Although this research examined small and medium-size wineries that are members of The Grand Cro wine association, findings are transferable to other high-quality Croatian wineries. Finally, this study has corroborated that wine tourism is an important factor for further development of wineries. The research conducted has proved that vintners have justifiable reason to include transition to wine tourism into their future medium-term development strategy because it might help them to drive bottle sales and increases the number of tourists visiting their wineries. More so, through the development of complementary tourist-oriented services, wineries might enhance their brand loyalty and awareness, creating a positive image of their wine product, and consequently the wine region.

\section{FUTURE RESEARCH DIRECTIONS}

Research based on larger sample of wineries in various other locations in Croatia would be of value added. Also, as this research focused on the supply side of the wine tourism market (wine producers), this research should be extended to the demand side of the wine tourism market (wine tourists). More so, future research projects could attempt to highlight differences between Croatian and similar wineries in other parts of the world.

\section{ACKNOWLEDGEMENT}

The authors would like to sincerely thank all the participants in this research for their willingness, time and effort in providing necessary data that enabled this project. 


\section{REFERENCES}

Asero, V., \& Patti, S. (2011). Wine tourism experience and consumer behaviour: the case of Sicily. Tourism Analysis, 16(4), 431-442.

Bakalović, R. (2018). Premium Croatian wine estates. Zagreb: GrandCRO.

Bruwer, J. (2003). South African wine routes: some perspectives on the wine tourism industry's structural dimensions and wine tourism product. Tourism Management, 24(4), 423-435.

Bruwer, J., \& Alant, K. (2009). The hedonic nature of wine tourism consumption: an experiential view. International Journal of Wine Business Research, 21(3), 235e257.

Bruwer, J., \& Lesschaeve, I. (2012). Wine tourists' destination region brand image perceptions and antecedents: conceptualization of a winescape framework. Journal of Travel \& Tourism Marketing, 29(7), 611-628.

Byrd, E.T., Canziani B., Hseih, Y., Debbage, K., \& Sonmez, S. (2016). Wine Tourism: Motivating visitors through core and supplementary services. Tourism Management, 52(2016), 19-29.

Cambourne, B., Macionis, N., Hall, C. M., \& Sharples, L. (2000). The future of wine tourism. In C. M. Hall, L. Sharpies, B. Cambourne, \& N. Maciones (Eds.), Wine tourism around the world: Development, management and markets (pp. 297-320). Oxford: Elsevier Science.

Cohen, E., \& Ben-Nun, L. (2009). The important dimensions of wine tourism experience from potential visitors' perception. Tourism and Hospitality Research, 9(1), 20-31.

Dodd, T. (1995). Opportunities and pitfalls of tourism in a developing wine industry. International Journal of Wine Marketing, 7(1), 5-16.

Drvenkar, N. \& Banožić, M. (2013). Regionalna Vinska Cesta Panonske Hrvatske. UDK, 634(8), 497-5.

Getz, D. (2000). Explore wine tourism: Management, development \& destinations. New York: Cognizant Communication Corporation.

Getz, D., \& Brown, G. (2006). Critical success factors for wine tourism regions: a demand analysis. Tourism Management, 27(1), 146-158.

Hall, C. M., Johnson, G., Cambourne, B., Macionis, N., Mitchell, R., \& Sharples, L. (Eds.). (2000). Wine tourism around the world: Development, management and markets. Oxford: Butterworth-Heinemann.

Jakšić, L., Njavro, M. \& August, H. (2016). Croatian Wine Market, Support Policy and Specific Obstacles to Wine Exports. Applied Studies in Agribusiness and Commerce, (10), 19-22.

McDonnell, A. and Hall, C.M. (2008). A framework for the evaluation of winery servicescapes: A New Zealand case. Pasos revista de tourismo Wine Tourism Research, 6(2), 231-47.

Telfer, D. J. (2000). The Northeast wine Route: wine tourism in Ontario, Canada and New York state. In C. M. Hall, L. Sharples, B. Cambourne, \& N. Macionis (Eds.), Wine tourism around the world (pp. 253-271). Jordan Hill, Oxford: Butterworth- Heinemann.

UNESCO (2019). World Heritage Sites. https://whc.unesco.org/en/tentativelists/5102/. Accessed $18^{\text {th }}$ November 2019.

Via Michelin (2019). https://www.viamichelin.com/web/Restaurants/Restaurants-Croatia?stars $=1$. Accessed $18^{\text {th }}$ November 2019.

Williams, P. (2001). Positioning wine tourism destinations: an image analysis. International Journal of Wine Marketing, 13(3), 42-58. 